\title{
PRESIDENTIAL ADDRESS HOW SUSTAINABLE IS AGRICULTURE'S PRESENT GROWTH?
}

\author{
COLIN BROWN \\ Wrightson Solutions, PB 1966, Dunedin \\ colinbrown@wrightson.co.nz
}

In 1996, at the annual grassland conference in Oamaru, I presented a paper that examined the economic and productivity trends in New Zealand agriculture over the previous 50 years. At that time, there had been a steady reduction in the real prices received for our agricultural products for the previous 50 years, our animal productivity on sheep and beef farms had remained relatively static over the same period, while dairy cow productivity had been slowly, but steadily rising.

The implication for farmers, and agriculture in general, was to reinforce the message that in order to retain profitability, one had to either:

- Get bigger, as in scale

- Get more productive, as in increased output per animal, or per hectare (while restraining cost of inputs)

- Change to a higher value output (eg. chilled meat vs. frozen meat)

In fact, over the past 10 years, our farmers, and the agricultural industry, have simultaneously achieved all three.

The price received by New Zealand farmers for their lamb has increased $89 \%$ since the late 1980 s, or $74 \%$ after taking away the benefit from exchange rate movements, at a time when the international price for frozen lamb carcases has dropped $12 \%$. Our price for beef has dropped $5 \%$ while the international price has dropped $45 \%$, and dairy prices have remained static during a time when butter prices have dropped $37 \%$, all in real terms (Table 1).
Crossbred wool, with a 54\% drop, and wheat, with a $42 \%$ drop, over the same time period, has not feared so well.

This is a remarkable achievement for lamb, because of the scale of the price increase, and also for dairy, because it occurred in tandem with a massive (108\%) increase in product volume in the same 1990 to 2003 period.

Also, we have experienced productivity gains unsurpassed in the history of New Zealand farming, particularly in sheep farming, with lambing percentage increasing $26 \%$ and lamb carcass weights $20 \%$, and wool weight per head by $10 \%$ since 1990 (Figures 1 and 2). These increases have resulted in total lamb production increasing $10 \%$, despite a $32 \%$ decrease in the national sheep flock since 1990.

Milksolids per cow has increased $21 \%$ over the same time period, as well as a $9 \%$ increase in cow stocking rate. At the same time, farms have continued to decrease in number, and increase in scale. The best example of this is in the dairy industry where the average herd size has increased $70 \%$ (Figure 3 ), and there are numerous examples of multiple unit ownership.

\section{Result}

As a consequence of these and similar productivity increases in other rural industries, the agricultural sector's contribution to GDP has increased by an average of $5.4 \%$ over the past 11 years, giving a cumulative increase of $80 \%$ over

Table 1 Percentage change in real prices for New Zealand commodities between the time periods 1985 - 1989 and $1999-2003$.

\begin{tabular}{lccc}
\hline Commodity & $\begin{array}{c}\text { Change in } \\
\text { New Zealand } \\
\text { real price }\end{array}$ & $\begin{array}{c}\text { Change in New Zealand } \\
\text { real price adjusted for } \\
\text { exchange rate }\end{array}$ & $\begin{array}{c}\text { Change in } \\
\text { international } \\
\text { real price }\end{array}$ \\
\hline Lamb & $89 \%$ & $74 \%$ & $-12 \%$ \\
Beef & $1 \%$ & $-5 \%$ & $-45 \%$ \\
Wool & $-43 \%$ & $-54 \%$ & $-43 \%$ \\
Dairy & $15 \%$ & $-2 \%$ & $-37 \%$ (butter) \\
Venison & $-27 \%$ & $-16 \%$ & $-26 \%$ \\
Wheat & $-22 \%$ & $-42 \%$ & - \\
\hline
\end{tabular}

Source data adapted from: International Monetary Fund, Livestock Improvement Corporation, MAF Policy, Meat and Wool Innovations Economic Service. 
Figure 1 Wool and lamb weights (1950-2003).

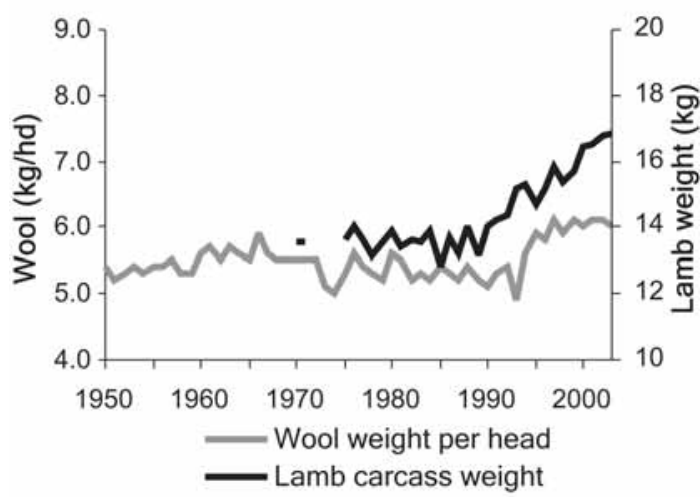

Source data adapted from: MAF Policy, Meat \& Wool Innovations Economic Service.

Figure 3 Dairy production (1950 - 2003).

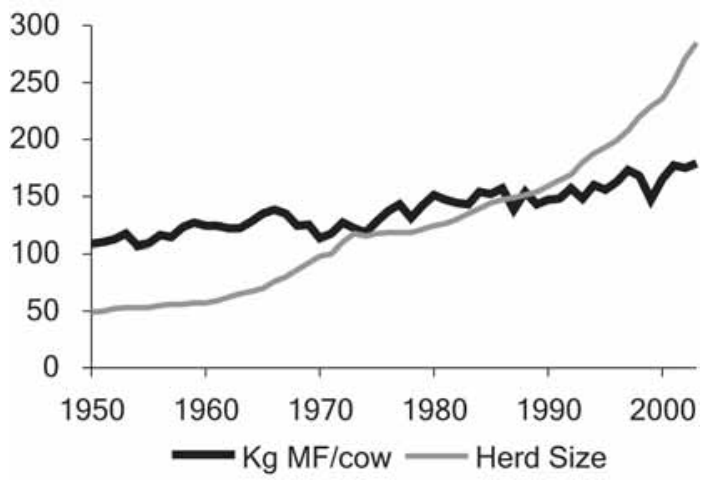

Source data adapted from: Livestock Improvement Corporation.

that time period (Davison 2004). Given that the New Zealand national economy grew $37 \%$ overall over that same time period, and agriculture contributes approximately $50 \%$ of exports, and $8 \%$ of GDP, it is reasonable to assume that much of the national growth can also be attributed to agriculture's strong performance.

There are a number of reasons for agriculture's contribution, of which some of the more important ones are:

- The technology adoption by our food processing companies, for example the technology advances employed by our meat processing companies that enable meat to be refrigerated, transported to the other side of the world, and still be safer and better quality product 11 weeks later, than freshly killed domestic product.

- The results of the agriculture reforms of the mid1980s that stopped the subsidies which had been distorting market signals and encouraging
Figure 2 Lambing percentage (1950-2003).

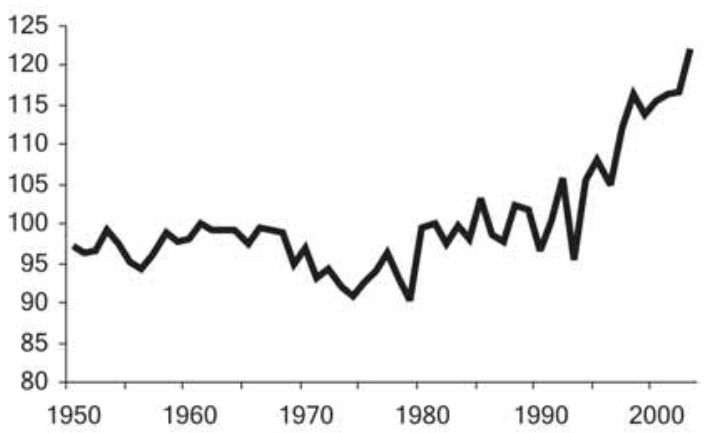

Source data adapted from: MAF Policy, Meat \& Wool Innovations Economic Service.

Figure 4 Forage yield of New Zealand bred white clover cultivars in eight trials under sheep grazing. Yield is expressed relative to the performance of Grasslands Huia (=100\%).

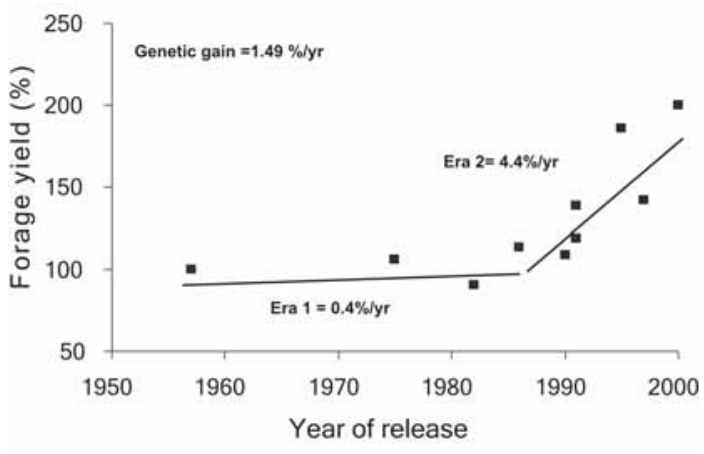

inappropriate resource allocation, for example the development of steep gorse covered gullies in an attempt to run underfed breeding ewes.

- Improved animal genetics, resulting from the cumulative impact of introduction of new sheep genes from overseas, such as the Finn and Texel, gene discoveries within our existing flocks, such as the Inverdale gene, and the fruition of the long investment in population genetics made by group breeding schemes.

- Improved pasture genetics. Woodfield (1999) reported how dramatically the nutritional value and productivity of our pasture cultivars had improved in cultivars released since the mid 1980 s, for example a $4.4 \%$ annual improvement of forage yield under sheep grazing from white clovers since 1985 (Figure 4).

This is where the New Zealand Grassland Association can also take some credit. Over the years, this conference, and Association, has been a major vehicle for the conduit of information for 
improving our pastoral farming, from our scientists to our agribusiness and farmer adopters. This contribution was recognised by the New Zealand Institute of Agricultural Science this year, in that its annual Technology Transfer Award went (for the first time to an organisation) to the New Zealand Grassland Association, in recognition of 70 years of successful technology transfer.

\section{But ...}

But is it sustainable? Most of these gains have been as a result of capitalising of the central government research carried out in the 1970's and 1980's. Woodfield, in his 2002 presidential address, reported on research that showed that new knowledge generated from agricultural research reached a peak about 11 years after its conclusion, and resulted in benefits for 23 years on average.

You may notice that most of the papers presented at this year's conference are actually funded by non-central government organisations. One of the positive attributes of the last 10 years has been the commitment by farmers under the Commodities Levies Act, to continue funding investment in R \& D. However, I suggest that the level of funding, by itself, is insufficient to maintain the foundation of strong agricultural research in this country.

Woodfield (2002) went on to comprehensively cover the importance of agricultural research to New Zealand's future. I will confine myself to saying that I still worry that the myth that agriculture is a "sunset industry", which found popular support in the 1980s, still seems to prevail in many sectors of today's decision and policy makers. This perception is particularly important when it is held by the influencers of our young people, such as school teachers, and the policy makers in government organisations whose mathematical logic is that to undertake research that achieves a 30\% gain in a $\$ 200$ million industry, is better than applying the same funds to achieve a $3 \%$ gain in a $\$ 13$ billion industry!

I have personally spoken with policy makers who point to the difference in productivity between top farmers and the bottom to average farmers, and then argue that the only effort needed is to lift the average. I suggest that it is akin to arguing that all rugby players are capable of being an All Black if coached properly.

The consequence of such a thought process is a real lack of young people pursuing science training through our universities, and a notable lack of young scientists in our research organisations.

Some simple biology tells us that this is unsustainable.

Given agriculture's importance to the national economy, we cannot afford to under invest in our $R$ \& $D$ for future benefit. Our society needs to recognise that such an investment is the cost of continuing to be able to play the game.

\section{REFERENCES}

Brown, C. 1996. Financial viability - a long term view. Proceedings of the New Zealand Grassland Association 58: 7-12.

Davison, R. 2004. Smoking performance from the pastoral sector. The New Zealand Meat Producer 32 (1).

Woodfield, D. 1999. Genetic improvements in New Zealand forage cultivars. Proceedings of the New Zealand Grassland Association 61: 3-7.

Woodfield, D. 2002. The importance of agricultural research to New Zealand's future. Proceedings of the New Zealand Grassland Association 64: $1-5$. 